\title{
HUBUNGAN JUMLAH TROMBOSIT DENGAN JUMLAH ERITROSIT PADA PASIEN INFEKSI VIRUS DENGUE DI RS X SURAKARTA
}

\section{THE RELATIONSHIP OF PLATELET WITH ERITHROCYTE COUNTS ON DENGUE VIRUS INFECTION PATIENTS IN X HOSPITAL SURAKARTA}

\author{
Muhammad Alim Abdul Majid Hidayatullah, Riandini Aisyah \\ Program Studi Pendidikan Dokter, Fakultas Kedokteran Universitas Muhammadiyah Surakarta \\ Korespondensi: Riandini Aisyah, S. Si., M. Sc. Email: ra202@ums.ac.id
}

\begin{abstract}
ABSTRAK
Supresi sumsum tulang merupakan kondisi yang biasa terjadi pada pasien terinfeksi dengue. Keadaan ini menyebabkan penurunan hematopoiesis. Secara teoritis, hal ini akan menurunkan jumlah trombosit dan eritrosit dalam darah tepi. Tujuan dari penelitian ini adalah untuk membuktikan korelasi antara jumlah trombosit dan eritrosit pada pasien terinfeksi dengue. Penelitian ini menggunakan analisis korelasi dengan pendekatan cross sectional. Data yang dikumpulkan dari rekam medis pasien sebanyak 40 pasien yang didiagnosis sesuai kriteria diagnostik WHO 2009, diagnosis dikonfirmasi dengan uji serologis, dan usia di bawah 14. Pasien yang memiliki riwayat anemia hemolitik autoimun (AIHA), purpura trombositopenia idiopatik (ITP), anemia, dan riwayat transfusi darah dikeluarkan dari penelitian ini. Kami menggunakan uji korelasi Pearson dengan software untuk menganalisa data. Rerata jumlah trombosit $=95.625(52,63) 10^{3} / \mathrm{mm}^{3}$ dan rerata jumlah eritrosit $=4,83(0,41) 10^{6} / \mathrm{mm}^{3}$. Uji korelasi Pearson antara jumlah trombosit dan eritrosit diperoleh nilai $r=0,215$ dan nilai $\mathrm{p}=0,182$, sehingga dapat diartikan bahwa tidak terdapat hubungan antara jumlah trombosit dan eritrosit pada pasien yang terinfeksi dengue.
\end{abstract}

Kata Kunci: infeksi virus dengue, trombosit, eritrosit

\section{ABSTRACT}

Bone marrow suppression is a common condition in dengue infected patient. It makes declining of hematopoiesis. Theoretically, it will decrease platelet and erythrocyte count in peripheral blood. The aim of this research is to prove the correlation between platelet and erythrocyte count in dengue infected patients. This research use correlative analysis with cross sectional approach. Data was collected from the patients medical record as much as 40 patients who was diagnosed according to diagnostic criteria by WHO 2009 as dengue, diagnosis was confirmed with serological test, and age under 14. Patient which had history of autoimmune hemolytic anemia (AIHA), immune thrombocytopenia purpura (ITP), anemia and history of blood transfusion were excluded from this research. We used Pearson correlation test with computer software to analyze the data. There were mean of platelet count is $95,625(52,63) 10^{3} / \mathrm{mm}^{3}$ and the mean of erythrocyte count is $4,83(0,41) 10^{6} / \mathrm{mm}^{3}$. The Pearson correlation test between platelet count and erythrocyte count obtained value of $r=0,215$ and value of $p=0,182$. There is no correlation between platelet count and erythrocyte count in dengue infected patients.

Keywords: dengue virus infection, platelet, erythrocyte

\section{PENDAHULUAN}

Infeksi virus dengue merupakan suatu penyakit arbovirus terbanyak di dunia. Infeksi virus dengue disebabkan oleh virus DENV 1, DENV 2, DENV 3, dan DENV 4. Virus dengue ditularkan melalui vektor nyamuk Aedes aegypti dan Aedes albopictus (Back \& Lundkvist, 2013; WHO, 2009).

Kasus infeksi virus dengue terutama menyerang negara tropis dan subtropis. Infeksi virus dengue sampai saat ini telah ditemukan di 125 negara di dunia. World Health Organization (WHO) memperkirakan terdapat 390 juta kasus infeksi virus dengue per tahun. Kematian akibat infeksi virus dengue dilaporkan 20 ribu orang per tahun (Bhatt, et al., 2013; Ferreira, 2012; Murray, et al., 2013). Angka kejadian infeksi virus dengue di Indonesia pada tahun 2013 dilaporkan 41,25 per 100.000 penduduk dengan angka kematian sebesar 0,7\%. Di Jawa Tengah dilaporkan 12.149 kasus 
dengan angka kematian 210 kasus. Di Surakarta sendiri dilaporkan terdapat 256 kasus dengan 4 kematian pada tahun 2014 (Dinkes Jateng, 2014; Kementrian Kesehatan RI, 2014).

Pembentukan trombosit dan eritrosit diawali oleh proses yang sama. Pada pemberian recombinant human erythropoietin ( $\mathrm{rHuEpo}$ ) yang ditujukan untuk meningkatkan produksi eritrosit didapatkan pula peningkatan trombosit (Loo \& Beguin, 1999). Hal tersebut membuktikan bahwa trombosit dan eritrosit mempunyai hubungan. Pada infeksi virus hubungan ini tidak selalu positif, namun berdasar teori supresi sumsum tulang, seharusnya terjadi penurunan jumlah trombosit dan jumlah eritrosit pada pasien infeksi dengue. Mengingat hal tersebut maka peneliti tertarik untuk mengetahui apakah terdapat hubungan antara jumlah trombosit dengan jumlah eritrosit pada pasien infeksi virus dengue.

\section{METODE}

Penelitian ini menggunakan desain analitik korelatif dengan pendekatan cross sectional untuk mengetahui hubungan jumlah trombosit dengan jumlah eritrosit pada pasien infeksi virus dengue. Teknik pengambilan sampel penelitian ini diambil dengan menggunakan metode consecutive sampling.

Penelitian dilakukan melalui data rekam medis berupa data kadar hematokrit, jumlah trombosit, dan jumlah eritrosit yang diukur pada hari ke-4 demam terhadap 40 pasien anak terinfeksi virus dengue yang memenuhi kriteria WHO, terkonfirmasi secara serologis, dan usia dibawah 14 tahun. Pasien dengan riwayat keganasan hematologi, autoimmune hemolytic anemia (AIHA), immune thrombocytopenia purpura (ITP), anemia dan transfusi darah sebelumnya kami keluarkan dari penelitian. Penelitian dilakukan di laboratorium RS X Surakarta pada bulan Oktober - Desember 2016. Uji Pearson digunakan untuk mengetahui hubungan dan tingkat korelasi antara jumlah trombosit dengan jumlah eritrosit pada pasien infeksi virus dengue yang diuji dengan bantuan software.

\section{HASIL DAN PEMBAHASAN}

Selama bulan Oktober - Desember 2016 terdapat 49 pasien anak yang terinfeksi virus dengue menurut kriteria WHO tahun 2009 di RS X Surakarta. Berdasarkan kriteria inklusi dan eksklusi maka didapatkan 40 pasien yang diikutkan dalam penelitian ini.

Pada penelitian ini didapatkan jumlah pasien laki-laki sebanyak 23 anak $(57,5 \%)$ dan perempuan sebanyak 17 anak (42,5\%). Rata-rata umur pasien anak laki-laki dan perempuan adalah 7,84 tahun. Karakteristik dari subyek penelitian disajikan pada Tabel 1.

Tabel 1. Karakteristik Hematologi Pasien

\begin{tabular}{lccc}
\hline \multicolumn{1}{c}{ Karakteristik } & $\begin{array}{c}\text { Laki-laki } \\
\mathbf{n = 2 3}\end{array}$ & $\begin{array}{c}\text { Perempuan } \\
\mathbf{n = 1 7}\end{array}$ & $\boldsymbol{p}$ \\
\hline Umur (tahun) & $2,31(4,42)$ & $8,56(4,54)$ & 0,347 \\
Hemoglobin (gr/dl) & $12,91(1,91)$ & $12,49(0,66)$ & 0,419 \\
Jumlah Leukosit $\left(10^{3} / \mathrm{mm}^{3}\right)$ & $5,67(2,44)$ & $5,93(1,84)$ & 0,547 \\
Jumlah Eritrosit $\left(10^{6} / \mathrm{mm}^{3}\right)$ & $4,89(0,48)$ & $4,74(0,28)$ & 0,242 \\
Jumlah Trombosit $\left(10^{3} / \mathrm{mm}^{3}\right)$ & $101,91(58,12)$ & $87,12(44,43)$ & 0,386 \\
Hematokrit $(\%)$ & $37,65(4,53)$ & $36,35(2,23)$ & 0,242 \\
\hline
\end{tabular}

Sumber : Data Penelitian Diolah, 2016

Uji normalitas data menggunakan tes Saphiro-Wilk didapatkan nilai $\mathrm{p}$ untuk jumlah trombosit dan jumlah eritrosit masing-masing 0,142 dan 0,139 . Hasil tersebut menunjukkan bahwa distribusi data penelitian normal maka uji korelasi yang dipakai untuk mengetahui korelasi antara jumlah trombosit dengan jumlah eritrosit menggunakan uji korelasi Pearson. Hasil uji korelasi didapatkan nilai $\mathrm{r}=0,215$ dengan nilai $\mathrm{p}=0,182$. Hasil tersebut menunjukkan bahwa terdapat korelasi yang lemah dan tidak bermakna antara jumlah trombosit dengan jumlah eritrosit pada pasien infeksi virus dengue.

Pada penelitian didapatkan pasien laki-laki (57,5\%) lebih banyak dibandingkan perempuan $(42,5 \%)$. Hasil ini sejalan dengan penelitian Angker dan Arima (2011) yang menyatakan bahwa pasien laki-laki lebih banyak daripada wanita pada 
kasus infeksi virus dengue. Perbedaan ini tidak mengindikasikan bahwa pasien laki-laki lebih rentan terhadap virus dengue, akan tetapi sikap orang tua yang lebih mengistimewakan anak lakilaki daripada anak wanita, pola penyebaran vektor infeksi virus dengue, dan lokasi serta waktu anak beraktifitas lebih berpengaruh terhadap banyaknya laki-laki yang terkena infeksi virus dengue (Angker \& Arima, 2011; Viennet, et al., 2014).

Rata-rata hitung leukosit dari subyek penelitian adalah $5,53(1,03-11,6) 10^{3} / \mathrm{mm}^{3}$. Hasil ini sejalan dengan penelitian Sovannah dan Haang (2012). Akan tetapi hasil ini berbeda dengan laporan penelitian Gregory et al (2011), Jameel et al (2012), dan Ghazali et al (2013). Ketiganya menuliskan bahwa leukopenia biasa menyertai infeksi virus dengue. Perbedaan ini mungkin terjadi karena perbedaan derajat infeksi virus dengue yang dijadikan subyek penelitian. Telah diketahui bahwa leukopenia lebih sering terjadi pada pasien dengan infeksi virus dengue berat (Haryoto, 2008).

Rata-rata jumlah trombosit pada penelitian ini menunjukkan angka 95,625 $(52,63) 10^{3} / \mathrm{mm}^{3}$. Hasil tersebut sesuai dengan kriteria WHO tahun 2009 yang menjadikan trombositopenia sebagai salah satu kriteria diagnosis infeksi virus dengue (WHO, 2009).

Nilai rata-rata kadar hematokrit pada penelitian ini adalah 37,1 (3,75)\%. Hasil ini menunjukkan bahwa subyek penelitian mengalami hemokonsentrasi merujuk pada penelitian Gomber et al (2001) dimana nilai cut off point untuk mengetahui hemokonsentrasi pada pasien infeksi virus dengue adalah 36,3\%. Hal tersebut sesuai dengan penelitian Rasyada et al (2014) dan Santoso (2014) yang menyimpulkan peningkatan nilai kadar hematokrit mempunyai hubungan dengan penurunan jumlah trombosit pada pasien infeksi virus dengue, namun berbeda dengan penelitian Hukom et al (2013) yang menyatakan tidak ada hubungan antara nilai kadar hematokrit dengan jumlah trombosit pada pasien infeksi virus dengue.

Hasil korelasi dengan menggunakan uji korelasi Pearson menunjukkan terdapat korelasi yang lemah dan tidak bermakna antara jumlah trombosit dengan jumlah eritrosit pada pasien infeksi virus dengue. Hasil penilitian ini selaras dengan penilitian Nelson et al (1966) yang menyatakan bahwa jumlah trombosit tidak berhubungan dengan jumlah eritrosit. Hal ini disebabkan karena eritrosit memiliki masa hidup yang lebih panjang dibanding trombosit sehingga mengaburkan hasil pemeriksaan darah tepi meskipun terjadi supresi sumsum tulang.

Krishnamurthy et.al (2016) melaporkan timbulnya supresi pada sumsum tulang akan mempengaruhi hematopoiesis dengan ditemukannya dua atau lebih penurunan cell lines pada infeksi virus dengue yang berjumlah $39,7 \%$. Dari 39,7\% tersebut didapatkan hanya 9\% terjadi penurunan cell lines trombosit dan eritrosit dengan presentase terbanyak adalah penurunan trombosit dan leukosit. Hal ini membuktikan bahwa jumlah trombosit tidak berhubungan dengan jumlah eritrosit pada pasien infeksi virus dengue.

Selain hal tersebut diatas, tidak adanya hubungan antara jumlah trombosit dengan jumlah eritrosit pada infeksi virus dengue dapat dijelaskan dengan beberapa alasan berikut:

1. Trombosit lebih rentan mengalami destruksi oleh lien daripada eritrosit

Ketika terjadi infeksi virus dengue, tubuh mampu membentuk antibodi anti dengue yang bereaksi silang dengan trombosit. Kompleks imun antara antibodi anti dengue dan trombosit kemudian akan dihancurkan oleh makrofag yang berada di lien, sehingga jumlah trombosit di dalam darah akan berkurang (Morel \& Ramirez, 2014).

Pada kasus infeksi virus dengue terjadi kebocoran plasma yang dapat menyebabkan nilai mean arterial pressure (MAP) rendah sehingga dapat mengakibatkan pasien mengalami hipotensi, asidosis dan hipoksia. (Pizzaro-Torres, 2016). Pada keadaan hipoksia, sel akan mengaktifkan Hypoxia-Inducible Factor-1 (HIF-1). HIF-1 merupakan pengatur utama dalam homeostasis oksigenasi di dalam sel. HIF1 tersusun atas sub-unit $\beta$ dan sub-unit $\alpha$ yang berfungsi sebagai pengatur oksigen dalam sel. Pada sub-unit $\alpha$, terdapat oxygendependent degradation (ODD) domain yang dihidroksilasi oleh prolin-hydroxylase-2 (PHD-2) menyebabkan sub-unit $\alpha$ rentan terhadap degradasi proteasomal ketika berada dalam kondisi oksigen yang normal namun stabil ketika berada pada kondisi hipoksia sehingga menyebabkan HIF1 akan aktif ketika berada dalam kedaan 
hipoksia (Ziello, et al., 2007).

Laderoute et al (2006) pada penelitiannya menyatakan bahwa HIF-1 dapat mengaktifkan AMP-activated protein kinase (AMPK) yang mampu menghambat proses eryptosis. Pada kondisi hipoksia, didalam eritrosit akan terjadi peningkatan $\mathrm{Ca}^{2+}$ yang akan membuka kanal kalium sehingga kalium dapat masuk ke dalam sel eritrosit dan akan mengakibatkan hiperpolarisasi. Eritrosit yang mengalami hiperpolarisasi kemudianakan mengakibatkan pengurangan volume sel eritrosit yang mengakibatkan terpaparnya phosphatidylserine (PS) pada membran sel eritrosit. PS yang terpapar dapat dikenali oleh makrofag sehingga eritrosit dapat di degradasi. Aktifnya AMPK akan menghambat peningkatan $\mathrm{Ca}^{2+}$ yang menyebabkan tidak terpaparnya PS pada membran sehingga eryptosis dapat dihindari (Foller, et al., 2009).

Trombosit yang bereaksi silang dengan antibodi anti dengue akan dihancurkan di lien sedangkan eritrosit mampu bertahan karena aktifnya AMPK pada kondisi hipoksia, maka menyebabkan tidak adanya korelasi antara jumlah trombosit dengan jumlah eritrosit pada pasien infeksi virus dengue.

2. Virus dengue mampu menginduksi kematian trombosit

B-cell lymphoma-extra large (bcl-xl) merupakan protein anti apoptosis yang dimiliki trombosit maupun eritrosit. Bclxl mengatur kematian dari trombosit dan eritrosit (Reuter \& Lang, 2009). Pada kasus infeksi virus dengue, virus dapat berikatan langsung dengan trombosit melalui heparan sulfat dan dendritic cell-spesific ICAM-3-grabbing nonintegrin (DC-SIGN). Ketika terinfeksi virus dengue, bcl-xl akan teregulasi negatif sehingga trombosit akan mengalami apotosis. Virus dengue tidak dapat berikatan langsung terhadap erirosit sehingga bcl-xl tidak teregulasi negatif sehingga eritrosit akan tetap bertahan (Hotzz, et al., 2011; Simon, et al., 2015). Perbedaan ini mengakibatkan tidak adanya korelasi antara jumlah trombosit dengan jumlah eritrosit.

3. Virus dengue bereplikasi di dalam trombosit namun tidak mampu hidup di dalam eritrosit Rondina \& Weyrich (2015) dan Sutherland et al (2016) melaporkan bahwa komponen darah unit PLT dan RBC yang didapat dari whole blood pasien infeksi virus dengue menunjukkan bahwa unit PLT mengandung virus dengue yang infektif dengan jumlah yang lebih banyak dibandingkan ketika darah pasien diambil. Sedangkan pada unit RBC jumlah virus dengue tidak lebih banyak dibandingkan ketika darah pasien diambil. Hal tersebut membuktikan bahwa virus dengue mampu bereplikasi pada trombosit namun tidak mampu bereplikasi pada eritrosit. Hal ini mengakibatkan banyak trombosit yang rusak akibat virus dengue. Ketika trombosit banyak yang rusak sedangkan eritrosit tidak mengalami kerusakan akibat virus dengue maka menyebabkan tidak adanya hubungan pada penelitian ini.

4. Trombosit yang terinfeksi virus dengue dirusak oleh monosit

Virus dengue mampu berikatan langsung dengan trombosit melalui DC-SIGN dan C-type lectin like receptor-2 (CLEC-2). Ikatan tersebut mampu mengaktifkan trombosit dan menyebabkan trombosit yang aktif adhesi dengan leukosit.

Trombosit yang berikatan dengan netrofil akan memicu apoptosis trombosit dan aktifnya trombosit memicu penghancuran trombosit itu sendiri di lien dan hepar sehingga menyebabkan jumlah trombosit dalam darah berkurang. Sedangkan dengue tidak mampu berikatan langsung dengan eritrosit, sehingga hal tersebut tidak mempengaruhi jumlah eritrosit di dalam darah (Assinger, 2014). Perbedaan tersebut menimbulkan tidak adanya hubungan pada penelitian ini.

5. Infeksi virus dengue menyebabkan cytopenia

Telah diketahui bahwa virus dengue mampu mensupresi sumsum tulang sehingga sering menyebabkan cytopenia. Manifestasi cytopenia pada infeksi virus dengue paling sering muncul adalah trombositopenia, sedangkan leukopenia dan anemia muncul tergantung dari derajat klinis infeksi virus dengue. Mengapa hal tersebut terjadi 
sampai saat ini masih belum diketahui dengan pasti. Karena perbedaan tersebut maka menyebabkan tidak adanya hubungan pada penelitian ini (Anwar, et al., 2012; Chauhan, et al., 2016).

\section{SIMPULAN DAN SARAN}

Berdasar penelitian yang telah dilakukan, didapatkan kesimpulan terdapat korelasi yang lemah dan tidak bermakna antara jumlah trombosit dengan jumlah eritrosit pada pasien infeksi virus dengue.

Dari penelitian di atas disarankan dilakukan pemeriksaan laboratorium secara serial untuk mengetahui hubungan jumlah trombosit dengan jumlah eritrosit pada pasien infeksi virus dengue dari waktu ke waktu. Perlu dibedakan antara infeksi virus dengue tanpa warning sign, dengan warning sign dan berat untuk mengetahui apakah ada hubungan antara jumlah trombosit dengan jumlah eritrosit pada masing-masing klasifikasi. Perlu dilakukan penelitian apakah gangguan organ mempunyai efek terhadap hubungan jumlah trombosit dengan jumlah eritrosit pada pasien infeksi virus dengue. Perlu dilakukan lebih lanjut apakah nilai mean arterial pressure (MAP) mempunyai efek terhadap hubungan jumlah trombosit dengan jumlah eritrosit pada pasien infeksi virus dengue.

\section{DAFTAR PUSTAKA}

Angker, M. \& Arima, Y., 2011. Male - Female Differences in The Number of Reported Incident Dengue Fever Cases in Six Asian Countries. Western Pacific Surveillance Response J, 2(2), pp. 17-23.

Anwar, B., Hassan, K., Asif, N. \& Parveen, R., 2012. Aplastic Anemia Associated with Dengue Fever. Journal of Islamabad Medical \& Dental College, Volume 2, pp. 97-8.

Assinger, A., 2014. Platelets and Infection - an Emerging role of Platelets in Viral Infection. Frontiers in Immunology, 5(649).

Back, A. T. \& Lundkvist, A., 2013. Dengue viruses - an overview. Infection Ecology and Epidemiology 2013, Volume 3.

Bhatt, S., Gething, PW., Brady, OJ., Messina, JP., Farlow, AW., Moyes, CL., 2013. The Global Distribution and Burden Of Dengue. Nature, Volume 496, pp. 504-7.

Chauhan, S., Naga, VS., Sood, A., Chatterjee, R., Kadu, R., Patel, DV., 2016. Severe Neutropenia in Dengue-look out for Hemophagocytic Lymphohistiocytosis. Open J Clin Med Case Rep, 2(9), pp. 1-6.

Dinkes Jateng., 2014. Profil Kesehatan Provinsi Jawa Tengah Tahun 2014. Semarang: Dinas Kesehatan Provinsi Jawa Tengah.

Ferreira, G. L., 2012. Global Dengue Epidemiology Trends. Rev. Inst. Med. Trop..

Foller, M., Sopjani, M., Koka, S., Gu, S., Mahmud, H., Wang, K., Floride, E., Schleicher, E., Schulz, E., Munzel, T., Lang, F., 2009. Regulation of Erythrocyte Survival by AMP-activated protein kinase. The FASEB Journal, Volume 23, pp. 1072-80.

Ghazhali, M., Intansari, U. \& Laksanawati, I., 2013. The Kinetics of White Blood Cells in Acute Dengue Infection. Trop Med J, 3(1), pp. 29-38.

Gomber, S., Ramachandran, VG., Kumar, S., Agarwal, KN., Gupta, P., 2001. Hematological Observations as Diagnostic Markers in Dengue Hemorrhagic Fever - a Reappraisal. Indian Pediatr, Volume 38, pp. 477-81.

Gregory, CJ., Lorenzi, OD., Colon, L., Sepu Iveda Garcia, A., Santiago, LM., 2011. Utility of the Tourniquet Test and the White Blood Cell Count to Differentiate Dengue among Acute Febrile Illnesses in the Emergency Room. PLOS Negl Trop Dis, 5(12).

Haryoto, E., 2008. Spektrum Klinis Demam Berdarah Dengue Pada Anak. Sari Pediatri, 10(3), pp. 145-50.

Hotzz, E., Tolley, ND., Zimmerman, GA., Weyrich, AS., Bozza, FA., 2011. Platelets in Dengue Infection. 
Haematology, 8(1-2), pp. 33-8.

Hukom, A. O., Warouw, S. M., Memah, M. \& Mongan, A. E., 2013. Hubungan Nilai Hematokrit dan Nilai Jumlah Trombosit Pada Pasien Demam Berdarah Dengue. Journal e-Biomedik, 1(1), pp. 707-11.

Jameel, T., Mehmood, K., Mujtaba, G., Choundry, N.,Afzal, N., Paul, RF., 2012. Changing Haematological Parameters in Dengue Viral Infections. J Ayub Med Coll Abbottabad, 24(1), pp. 3-6.

Kementrian Kesehatan Republik Indonesia., 2014. Infodatin. Situasi Demam Berdarah Dengue di Indonesia, 22 April, pp. 1-6.

Krishnamurthy, V., Rajashekar, R. \& Doreswamy, S. M., 2016. Peripheral Cell Line Suppression in Dengue Infection in Relation to Serological Status. Asian Journal of Medical Sciences, 7(5), pp. $52-5$.

Laderoute, KR., Amin, K., Calaoagan, JM., Knapp, M., Le, T., Orduna, J., Foretz, M., Viollet, B., 2006. 5'-AMP-Activated Protein Kinase (AMPK) Is Induced by Low-Oxygen and Glucose Deprivation Conditions Found in Solid-Tumor Microenvironment. Moleculer and Celluler Biology, 26(14), pp. 5336-47.

Loo, M. \& Beguin, Y., 1999. The Effect of Recombinant Human Erythropoietin on Platelet Counts Is Strongly. Blood, 93(10), pp. 3286-93.

Morel, Z. \& Ramirez, A., 2014. Autoimmune Response in Children With Dengue. Case Reports. Reumatol Clin, 10(4), pp. 257-9.

Murray, N. E. A., Quam, M. B. \& Wilder-Smith, A., 2013. Epidemiology of Dengue: Past, Present and Future Prospects. Clinical Epidemiology, Volume 5, pp. 299-309.

Nelson, ER., Tuchinda, S., Bierman, HR., Chulajata, R., 1966. Haematology of Thai Haemorrhagic Fever (dengue). Bull World Health Organ, 35(1), pp. 43-4.

Pizzaro-Torres, D., 2016. Dengue With Severe Plasma Leakage: A New Monitoring Approach. Acta Med Costarric, 58(3), pp. 115-21.

Rasyada, A., Nasrul, E. \& Edward, Z., 2014. Hubungan Nilai Hematokrit Terhadap Jumlah Trombosit pada Penderita Demam Berdarah Dengue. Jurnal Kesehatan Andalas, 3(3), pp. 343-7.

Reuter, S. \& Lang, D., 2009. Life Span of Monocytes and Platelets: Importance of Interactions. Frontiers in Bioscience, Volume 14, pp. 2432-47.

Rondina, M. \& Weyrich, A., 2015. Dengue Virus Pirates Human Platelets. BLOOD, 126(3), pp. 286-7.

Santoso, A. M., 2014. Hubungan Jumlah Trombosit dengan Kadar Hematokrit Pasien Demam Berdarah Dengue (DBD). Surakarta : Universitas Sebelas Maret. Skripsi.

Simon, A., Sutherland, M. \& Pryzdial, E., 2015. Dengue Virus Binding and Replication by Platelets. BLOOD, 126(3), pp. 378-85.

Sovannah, T. \& Haang, V., 2012. Correlation between Fever and Leukocyte in Dengue Infection, a Clinical Observation. Adv Lab Med Int, 3(1), pp. 9-13.

Sutherland, M., Simon, AY., Serrano, K., Schubert, P., Acker, JP., Pryzdial, ELG., 2016. Dengue Virus Persist and Replictes During Storage of Platelet and Red Blood Cell Units. Transfusion, Volume 56, pp. 1129-37.

Viennet, E., Ritchie, SA., Faddy, HM., Williams, CR., Harley, D., 2014. Epidemiology of Dengue in a High-Income Country: a Case Study in Queensland, Australia. Parasites \& Vectors, Volume 7, p. 379.

WHO, 2009. Dengue Guideliness for Diagnosis, Treatment, Prevention, and Control. New ed. Geneva: WHO Press.

Ziello, J., Jovin, I. \& Huang, Y., 2007. Hypoxia-Inducible Factor (HIF)-1 Regulatory Pathway and Its Potential for Therapeutic Intervention in Malignancy and Ischemia. Yale Journal of Biology and Medicine, 80(2007), pp. 51-60. 